\title{
Structure, conduct and performance paradigm in assessing travel agency performances
}

\author{
Gabriela Cecilia STĂNCIULESCU \\ The Bucharest University of Economic Studies, Bucharest, Romania \\ Elisabeta Ilona MOLNAR \\ Partium Christian University, Oradea, Romania \\ elis@partium.ro
}

\begin{abstract}
The purpose of this paper is to present and exemplify traditional and neoclassical approaches to market structure and tourism firm performance analysis. The paper tackles some of the industrial economic thinking trends which were meant to fill the gaps left by the traditional approaches. Two approaches stand out from among the industrial economic trends: SCP paradigm and game theory. The results show that the strategy tourism operators prefer is to practise high prices; however there is no certainty that the competitors would adhere to such an idea at the beginning or during the season.
\end{abstract}

Keywords: SCP paradigm, tourism firm, game theory.

\section{Introduction}

Two approaches stand out from among the industrial economic trends. The first one, the structure-conduct-performance (SCP) paradigm, is used mostly in the empirical studies on manufacturing companies. Although subject to criticism, particularly due to the theoretical grounds of the analysis, the paradigm continues to be a useful working tool, being relevant in many domains, among which tourism. The second, a more recent approach, is game theory, which analyses the strategies companies should adopt when considering the competitors' possible actions and reactions. Game theory has been extensively used in oligopoly situations and facilitated the understanding of the interactions within the company and of the results of these actions in their dynamics. This theory seems to be highly important in comprehending the conduct and strategies of the actors in tourism.

Before analytically studying these developments, let us summarise the approaches that have been adopted in the economy with regard to the market where companies operate and the ways in which they influence companies' structure and conduct. We shall first discuss the major economic trends in industry, which contribute to explaining phenomena versus the descriptive approaches on the offer in tourism and the way it changes. Next, we shall present the behavioural theories of the Austrian schools of economics: evolutionist, institutional and psychological theories.

Although they do not always apply to tourism offer and they do not exist in tourism literature, these concepts are useful when defining the context required by an analysis and they will continue to be useful for future research work. Then, we shall explain the SCP paradigm pointing to its applications in services, in the case of intermediaries in tourism included. We shall asses its strengths, as well as its limits. We shall point out the role of game theory in explaining the strategies of the tourism companies in a dynamic context, just as the related changes in the structure of tourism markets. 


\section{Literature review}

The SCP paradigm (Chamberlin 1933, Bain 1956) dominated the economic thinking until the '80s. According to this paradigm, the structure of the market where companies operate is, in the last analysis, the decisive factor of the management and of the performance model, and is measured by indicators, such as profitability. Market structure variables like number of buyers and sellers, or market structure concentration degree are supposed to be stable in this paradigm.

The SCP paradigm is an empirical analysis which accepts the idea that as a rule market structures differ from the concept of perfect competition. Thus, if the companies set their prices high above marginal costs, government interventions will occur and measures will be taken to stimulate competition. Therefore, SCP is politically oriented. Big steps ahead have been made despite the seeming conflict between the theoreticians' wish to develop general offer models and the empirics' insistence to establish how firms behave, with stress on understanding what determines the offer model. So, the relations between intermediaries and consumer goods manufacturers and between employers and employees are better understood. Models provide explanations and better reflect reality. Anyway, progress was made mostly in developing market behavioural models, incorporating game theory elements and resorting to notions like product differentiation, market segmentation, price discrimination, firms' reactions to the prices imposed by their rivals and competitive strategies, which have nothing to do with prices. Before examining how the various approaches explain conduct on tourist markets, it is useful to review the firms' behavioural theories, which have developed apart from basic economic analyses.

\section{SCP paradigm assessment in the context of tourist markets}

The SCP paradigm is recommended when analysing the characteristics of market structure, firms' conduct and performances, allowing for the utilisation of a wide range of variables. Likewise, SCP provides a useful framework which includes the domains of activity and the markets as basis for analyses.

The SCP paradigm should not be used only for analysis but also as a starting point in examining economic problems in general. Its strength resides in the fact that it is a method appropriate to provide a perspective of the market as against that based only on one sector. It has the merit of offering a holistic vision and of identifying a wide range of variables subject to examination. The method highlights the importance of certain characteristics, for instance entry conditions, important for the number and size of firms, as well as market competitiveness, firm's conduct with regard to prices, strategies and profitability. Undoubtedly, if, as said, the tourist markets are not only complex but also unbalanced, then the latest results of the economic analyses on the sector, which take into consideration their dynamic nature, should also be used. Indeed, the economic explanations about the tourist sector and business strategies should not be confined by a specific analysis framework such as the SCP paradigm. The dynamic processes that influence the conduct of the tourist companies, with which the latter are confronted, the changes in the market structures and the various ways of performing analyses, provided by diverse economic thinking trends, can be taken into consideration by the game theory, whose relevance for tourism will be discussed next.

An overall approach, the SCP paradigm should not be quantified as just an analysis but also as a starting point for a laborious examination of the economic problems in general. Its strength resides in the fact that it is an appropriate, propitious and proper method that provides a market perspective as against that based exclusively on one 
sector. Primarily, it has the theoretical merit of providing a holistic vision and of identifying a wide gamut of variables, subject to analytic tests. This method highlights the importance, the relevance of certain characteristics, for example the entry conditions, which have a not at all negligible influence on the number and size of companies and points to market competitiveness, firms' conduct with regard to prices, strategies and profitability. Indubitably, if, as previously said, the tourist markets are not only complex but also unbalanced, the latest results of the economic analyses on the sector, which take into account its synergetic as well as dynamic nature, should also be used. As far as a tour operator is concerned, its business strategy is built on the need to provide quality services to its customers, to the end of fully meeting their requirements. This can be done by recruiting the best teams and tailoring packages based on customers' needs. In time, the marketing campaign will lead to a better knowledge of the services provided on several markets. Customers will have the chance to focus more on what they want before rushing to buy a tourist package. The advertising materials are professional, and they reflect the image and reputation of the agency. The promotion materials will be well designed so that the customers could easily understand the types of services provided and the advantages of using them. In a nutshell, the following targets should be attained:

- to attract foreign tourists

- to offer quality tourist packages depending on budget and allotted time

- to stabilise a market which should ensure profitability, growth and success in the short and long run

- to commit to supporting the growth and development of tourism in Romania

- to positively contribute to the community and the environment.

Most certainly one of the paths to success of the agency is market segmentation so as to be able to identify the needs of the market components and to implement its own strategies. Besides this process, the agency plans to make itself known to its potential customers by all advertising means. The sales strategy is based mainly on a good co-operation with hotels and partner travel agencies. Consequently, the factors leading to success must include the following:

Table 1. SCP paradigm elements, as highlighted by the SWOT analysis

\begin{tabular}{|c|c|}
\hline Strengths & Opportunities \\
\hline $\begin{array}{l}\text { Young team, specialised in tourism, that can cope } \\
\text { with any situation; } \\
\text { Each employee fluently speaks a foreign } \\
\text { language; } \\
\text { High street agency, very good accessibility, } \\
\text { central zone; } \\
\text { Overall tourist services provided (insurance, } \\
\text { accommodation, transport, tourist assistance, } \\
\text { rent-a-car, transfers, event reservations); } \\
\text { Direct interaction with customers; } \\
\text { Successful implementation of marketing } \\
\text { strategies; } \\
\text { Lowest prices in the area; } \\
\text { System operated through a functional and 'easy } \\
\text { to handle' website; } \\
\text { Promotion of tourist services by means of } \\
\text { brochures and ads; } \\
\text { Differentiated prices pursuing customer } \\
\text { retention; } \\
\text { Own designed Inclusive Tour packages; } \\
\text { Specialised soft for room reservations; }\end{array}$ & $\begin{array}{l}\text { Measures taken by the government to attract } \\
\text { tourists and sustain local entrepreneurs in } \\
\text { tourism are opportunities that should not be } \\
\text { missed; } \\
\text { Maximum advantage should be taken of the } \\
\text { continuously growing tourist flow. These } \\
\text { growths will also be backed by the government } \\
\text { campaigns of attracting tourists and by the new } \\
\text { marketing campaigns of non-government } \\
\text { organisations and associations of employers in } \\
\text { tourism; } \\
\text { Presently, there are few agencies dwelling } \\
\text { professionally on the incoming business tourist } \\
\text { flow, rent-a-car businesses are growing while } \\
\text { foreign investments are expanding, which bring } \\
\text { along a flow of foreigners; } \\
\text { The current trend in international tourism shows } \\
\text { that most of tourists want to enrich their tourist } \\
\text { experience rather through diversified and a little } \\
\text { "different" offer than through the already } \\
\text { classical "sun \& sea" holidays. }\end{array}$ \\
\hline
\end{tabular}




\begin{tabular}{|c|c|}
\hline $\begin{array}{l}\text { Co-operation with big national and international } \\
\text { tour operators in order to diversify the offer and } \\
\text { to provide customers with packages meeting } \\
\text { their needs to the best; } \\
\text { Drawing in leisure clientele; } \\
\text { Technological and staff development in the next } \\
\text { two years. }\end{array}$ & \\
\hline Weaknesses & Threats \\
\hline $\begin{array}{l}\text { Recent movement of the agency which } \\
\text { results in less customers in the first } \\
\text { quarter; } \\
\text { Small number of employees; } \\
\text { Limited parking places in the area; } \\
\text { Dependence on big tour operators; } \\
\text { Big capital movement, small profit. }\end{array}$ & $\begin{array}{l}\text { Current increase of the number of tourist brings } \\
\text { about the increase of the number of agencies on } \\
\text { the market. This leads to a tougher competition } \\
\text { from them; } \\
\text { Electronics retailers start outsourcing their profit } \\
\text { and try to make best use of available space, } \\
\text { which results in travel agencies opened within } \\
\text { malls; } \\
\text { The national carrier (Romanian post) the Nufarul } \\
\text { laundry shop chain and the Romanian Lottery } \\
\text { Agency plan to open travel agencies on their } \\
\text { locations in order to increase their profits; } \\
\text { Existing competition, which will pump large } \\
\text { resources in marketing and advertising. }\end{array}$ \\
\hline
\end{tabular}

Source: Author`s own research.Table based on research performed by a tourism firm (tour operator).

The marketing strategy requires focus on designing tourist packages for these market segments. Tourist demand must be permanently studied so that the best packages should be prepared in time. Romanian tourists will be offered predefined Inclusive Tour type packages or custom-tailored packages, according to their preferences. Consequently, in order to attain this goal, the following objectives must be achieved:

To establish the agency's reputation as a flexible agency that takes into account its customers' needs, boasting a multitude of tourist offers. This is possible only with the help of solid marketing strategies and co-operation contracts with the best suppliers of tourist services.

To develop the business department to be able to cover this tourist sector as well. To this end there should be offers targeting this type of travel, which means reservations at the best hotels in Romania and abroad, tourist assistance by specialised guides, contracts signed with deluxe rent-a-car agencies and extra package reservation services. Strategy is to develop the business by increasing the number of customers mainly through the quality provided and the conduct of the staff that will relate directly with the customers. All the criteria from customer satisfaction, service development, and competitive prices to staff attitude shall be permanently under scrutiny as areas subject to improvement. The co-operation with the best suppliers of tourist services (hotels, travel agencies) has already been adopted as key strategy.

Firm means people, and one need well trained people to sell quality tourist packages. Training activities should be organised to make sure that the staff will always meet customers' expectations. Likewise, there is no productivity in the absence of a good co-operation among colleagues. In order to always have competitive results, one must optimise staff as much as possible. For a positive growth, there should be the right person in the right place at the right time. The team should be developed so that people should grow as the firm develops a tacit partnership beneficial to both sides (Dima et al., 2016). 
Differentiation from competition is a key element of the marketing strategy. In terms of marketing, one has to make sure that the name and services of the agency are permanently on customers' minds.

The types of tourist packages the travel agency promotes are diversified, depending on requests. Likewise, by the number of days included, the packages are mostly of a medium type (7-14 days), but upon customers' request they can be changed into short-packages (2-5 days) or long-packages (14-21 days). Examples of tourist packages offered by travel agency can be found on www.cosmotravel.ro - the site of the travel agency.

Taking into account the diversity of requests, travel agency has structured its offer so as to meet as many as possible of tourists' requirements. So, the agency provides a full range of tourist services: plane tickets, accommodation in the country and abroad, event planning (incentive trips, team building, conferences, seminars, product launching, workshops), rent-a-car, tourist packages (stays, circuits/tours, cruise, city breaks, last minute trips), medical insurance. Most of both the offer and the demand focus on ticketing, irrespective of the season. As far as tourist packages are concerned, most of the offer is concentrated on two seasons: winter and summer, the rest of the year being in poor demand. Likewise, the promotion activity is more intense during season time, the company having to make its tourist offer known, the changes being made depending on the season. In winter, the activity focuses on the mountain resorts, where winter sports can be practised (particularly the mountain resorts in Austria) as well as on other resorts that provide conditions for spending a pleasant sedentary holiday or for spa treatments. Winter celebrations represent an important period of the year when people have free time and try to spend their mini-holiday in a pleasant way. Summertime is the period of most intense activity for the agency, with holidays and vacations, when demand reaches its peak.

\section{Methodology}

Game theory can be used both in explaining the conduct and in forecasting the results of the strategies referring to price setting, product selection and differentiation, advertising, capital investments, mergers and acquisitions, entry barrier setting. Observing the firms' conduct and interactions, one may understand how markets operate and evolve; this is an important attribute in analysing certain segments of the tourism sector that have just emerged and are still unstable. It is important not only to make a distinction between co-operative and non-co-operative games but also to make a distinction with regard to the behaviour of the participants, the objectives and knowledge of the reactions of rivals. Usually, simple simulations presuppose: competitors' rational behaviour, profit maximisation, perfect and symmetrical information, so that the firms know the structure of their rivals' prices, their turnover, prices and others, just as the conditions of the market where they operate. Such restrictive assumptions can be reduced, in more complex situations, with the help of the game analysis.

Moreover, as far as the co-operative and non-co-operative games are concerned, it is possible to apply "one way" games or "repeated" games and, even more, a distinction can be made between simultaneous games and sequential games. In certain conditions, the firms, aware of the illegal character of cartels in some countries, can initially have a non-co-operative strategy, and, subsequently, a behaviour that can lead to the establishment of tacit cartels. For instance, they maintain high prices, knowing that their competitors will do the same. The "one way" games apply when all decisions 
are made once, for example, to make a capital investment for a new product or to place an entry barrier. The other way round, the repeated games are recommended when the best idea is to gain short-term advantages. For instance, the price and product differentiation strategies are changed frequently, and the rival firms periodically engage in non-competitive games. There are situations in tourism when this really happens: airlines and ferryboat companies and tour operators, which engage in price wars in order to increase their market share, while price differentiation is an attempt to expand their market or satisfy a new customer segment. There is a distinction between simultaneous and sequential games, since they stand for different market situations, which entail changes in the strategies. In certain cases, for instance in Cournot's duopoly model, all firms make decisions on their output level all at the same time, while in the Stackelberg analysis a firm makes such a decision independently, and its rivals react. This is an important factor when the first that makes a move on the market can have an advantage. In tourism, simultaneous decisions are often made in the case of short-term changes with regard to demand levels: for example, by airlines, ferryboat companies and hotels. Sequential or reactive strategies apply also to tour operators where time has a far greater importance.

\section{Research results}

The research presents the case of a summer holiday packages, when a tour operator offers discounts if they are purchased in advance, the rivals will most certainly do the same if they feel they are going to lose their market share.

Certain subsectors of the tourist offer are structured in oligopolies and that is why the strategies are common in point of price setting, offer level, product differentiation and marking, market segmentation, advertising, innovation and entry barriers. Furthermore, account could be taken of the circumstances when a key firm can exert a dominant strategy, possibly because of some particular features, such as the trademark, offering an optimum strategy, independent from that of its competitors. In order to exemplify the application of game theory to tourism we shall discuss about advertising, price setting decisions and entry barrier building - the tour operators could be confronted with. The first element presents the non-competitive and simultaneous game of the impact advertising has on size and market share; the second, on price setting, is an example of non-co-operative and repeated game, the third is the "one way" and non-co-operative case. The second and the third show possible results of a cooperative behaviour.

The simplest situation is when the firms have a dominant strategy, hold an optimum position and do something different from their competitors. This basic concept of game theory is illustrated by tour operators, which decide whether and how to advertise. It is assumed that advertising is a competitive activity of tour operators - in order to take hold of an as big market share as possible - as well as informative. Table2 presents a $2 \times 2$ matrix), in a game with two firms that make up a duopoly (a form of oligopoly) which pays tour operator $\mathrm{X}$ to advertise or not.

Tour operator $X$ will advertise, because this is the strategy that is best for it. If $Y$ does not advertise, the gain for $\mathrm{X}$ is 25 , and if $\mathrm{Y}$ advertises, $\mathrm{X}$ will gain 20 . Identically for $\mathrm{Y}$, the gain is 10 , respectively, if both advertise, and 15, if $X$ does not. One may see that if both advertise, the total gain will be 30 (20X, 10Y) to secure a stable position. 
Table 2. Advertising effect following a dominant strategy

\begin{tabular}{|c|c|c|c|}
\hline & Tour operator Y & \\
\hline & & With advertising & Without advertising \\
\hline \multirow[t]{2}{*}{ Tour operator $\mathrm{X}$} & With advertising & $20(10)$ & $25(0)$ \\
\hline & Without advertising & $10(15)$ & $15(5)$ \\
\hline
\end{tabular}

Source: Stanciulescu, Gabriela, Travel Agency Management, AES Publishing House, București, 2013, p.14

If $\mathrm{X}$ has no dominant strategy, the best decision depends on what $\mathrm{Y}$ is going to do. PICBE $\mid \mathbf{8 0 8}$ For instance, in the case of advertising in Table 2, if the payment for $\mathrm{X}$ is 40 , neither of them advertising (right bottom cell), then X's strategy is determined by what Y does. If $Y$ advertises, so should $X$; but if $Y$ does not, nor should $X$, since the payment is by far bigger by adapting this strategy. Therefore, $\mathrm{X}$ must guess what $\mathrm{Y}$ is going to do. Since $\mathrm{Y}$ has the same dominant strategy, as before, it is obvious that it will advertise because whatever $\mathrm{X}$ does is the best action. If $\mathrm{X}$ makes a correct assumption about Y's actions, which is also the model assumption, a stable equilibrium can be struck.

When there is no dominant strategy, the brochures should be launched sometime in August-October (maybe when advertising would extend more the market than the market share for certain tour operators); the problem that could occur is whether a stable equilibrium may be attained. This happens when a relaxation of the rational conduct and a correct interpretation of strategies and of competitors' action are intended. Game theory shows that there can be several equilibria or that there is none. Consequently, it is possible to have an explanation why instability occurs in certain sectors where certain conditions prevail.

Examples of dilemmas facing firms in their decisions on prices can be used to demonstrate this aspect. In the second half of the year, tour operators launch the brochures for the next summer season. Due to the market extension degree and to the fix capacities of the airlines and of the hotels, which may be in excess in offseason, individual tour operators admit that all customers not only are sensitive to prices but also can postpone their decision to buy, hoping for subsequent discounts. Tour operators can consider the holiday offer at lower prices in order to stimulate the consumer to make an early booking. But, due to very low margins in this domain, such a strategy can lead to a very small profit or even to loss. The strategy everybody prefers is that of high prices, but there is no certainty that the competitors would adhere to such an idea at the beginning or during the season.

Repeated games can thus represent real life, forecasting the results in a feasible way, the main objective of simulating the market, the identification of the most valid strategy.

\section{Conclusions}

The SCP model also assesses the concentration degree, as a competitiveness indicator on the market. In tourism, concentration shows particularly in: tourist air transport and the development of hotel and restaurant chains. Game theory can be used both to explain conduct and to forecast product, price, distribution and capital investment strategies. There are several types of games: one way games; repeated games; simultaneous games; sequential games; cooperative and non-cooperative games.

In the case of tourism, the decisions made following the application of game theory are often made for short term and under the strong influence of the tourist firm's external factors. 


\section{References}

Bain, J.S. (1956). Barriers to new competition, Cambridge, Mass.

Chamberlin, E (1933). Theory of Monopolistic Competition, Cambridge, Mass, 6.

Chamberlin, E. (1936). The theory of monopolistic competition: a re-orientation of the theory of value, Cambridge, MA.: Harvard University Press.

Dima, A. M., Hadad, S., \& Cantaragiu, R. (2016). A conceptual analysis of business- PICBE|809 university knowledge transfers in the energy field. ENERGY, CLIMATE CHANGE AND SUSTAINABILITY, 201-207.

Martin, C.A. and Witt, S.F. (1987). Tourism demand forecasting models. Tourism Management, 8(3), 233-246. doi:10.1016/0261-5177 (87)90055-0.

Robinson, J. (1933). The economics of imperfect competition. London:Maccmillan.

Simon, H.A. (1955). A Behavioral Model of Rational Choice. The Quarterly Journal of Economics, 69(1), 99. doi:10.2307/1884852.

Stigler, G.J. (1972). Monopolistic Competition in Retrospect. Readings in Industrial Economics, 131-144. doi:10.1007/978-1-349-15484-5_8.

Stănciulescu, G. (2006). Management of tourism operations. București: Editura A.S.E.

Stănciulescu, G. (2013). Management of travel agency, Bucureşti: Editura A.S.E.

Stiglitz, J. E. (1989). Chapter 13 Imperfect information in the product market. Handbook of Industrial Organization Handbook of Industrial Organization Volume 1, 769847. doi:10.1016/s1573-448x(89)01016-2. 